Vol. 1, No. 2, 2019

\title{
ANALISIS KESALAHAN SISWA DALAM MENYELESAIKAN SOAL MATEMATIKA BERDASARKAN ANALISIS NEWMAN
}

\author{
Ganik Wahyuningtias Sunardiningsih ${ }^{1}$, Sri Hariyani ${ }^{2}$, Trija Fayeldi $^{3}$ \\ Pendidikan Matematika, Universitas Kanjuruhan Malang ${ }^{1,2,3}$ \\ greeneyganik@gmail.com¹ ${ }^{1}$, srihariyani@unikama.ac.id ${ }^{2}$, trija_fayeldi@unikama.ac.id ${ }^{3}$
}

\begin{abstract}
Abstrak. Fokus penelitian ini adalah untuk menganalisis kesalahan siswa dalam menyelesaikan soal matematika berdasarkan analisis Newman. Jenis penelitian ini adalah penelitian deskriptif dengan pendekatan kualitatif. Hasil penelitian menunjukkan bahwa: 5 subjek mengalami kesalahan membaca, yaitu siswa tidak mampu memaknai arti setiap kata, istilah atau simbol dalam soal; 12 subjek mengalami kesalahan memahami, yaitu siswa tidak mampu memahami informasi yang diketahui dengan lengkap dan tidak mampu memahami apa yang ditanyakan; 8 subjek mengalami kesalahan transformasi, yaitu siswa tidak mengetahui rumus yang akan digunakan dan tidak mengetahui operasi hitung yang akan digunakan; 11 subjek mengalami kesalahan keterampilan proses, yaitu siswa tidak mengetahui prosedur atau langkah-langkah yang akan digunakan; dan 13 subjek mengalami kesalahan penulisan jawaban akhir, yaitu siswa tidak menemukan hasil akhir yang sesuai dengan langkah-langkah yang digunakan dan tidak menuliskan jawaban akhir sesuai dengan kesimpulan yang dimaksud dalam soal.
\end{abstract}

Kata Kunci: Analisis Kesalahan; Soal Matematika; Analisis Newman

\section{PENDAHULUAN}

Matematika merupakan salah satu bidang studi yang diajarkan di setiap jenjang pendidikan mempunyai peranan sangat penting dalam mencerdaskan peserta didik. Matematika mengembangkan kemampuan berpikir kritis, analitis, dan logis melalui penyelesaian masalah. Penyelesaian masalah memerlukan berbagai keterampilan seperti interpretasi informasi, perencanaan dan penyelesaian, pengecekan hasil dan alternatif strategi (Intaros, Inprasitha, \& Srisawadi, 2014).

Dalam pembelajaran, seorang guru sebaiknya melakukan analisis terhadap kesalahan yang dilakukan oleh siswa. Menurut (Karnasih, 2015) sepanjang proses penyelesaian masalah berlangsung, seringkali siswa membuat kecerobohan, serta ada beberapa siswa yang memberikan jawaban yang salah. Siswa harus dilatih menyelesaikan soal matematika secara urut dan jelas. Latihan menyelesaikan soal dimaksudkan untuk merangsang kepekaan siswa dalam mengkesplorasi masalah untuk mendapatkan ide penyelesaian (Hariyani, Yuwono, Sa'dijah, \& Rahardjo, 2016). Untuk melatih siswa mengurangi kesalahan yang dilakukan saat mengerjakan soal, prosedur Newman bisa digunakan untuk menentukan jenis kesalahan siswa saat pengerjaan soal matematika.

Analisis kesalahan Newman didasarkan pada kesalahan antara lain membaca (reading), memahami (comprehension), transfromasi (transformation), keterampilan proses (process skill), dan penulisan jawaban (encoding) (Flagg, 2014). Pada tahap membaca (reading), siswa dapat membaca atau mengenal simbol-simbol dalam soal, selain itu siswa memaknai arti kata, istilah atau simbol dalam soal. Pada tahap memahami (comprehension), siswa memahami informasi yang diketahui dengan lengkap, dan siswa memahami apa saja yang ditanyakan dengan lengkap. Pada tahap transfromasi (transformation), siswa dapat membuat model matematis dari informasi yang disajikan, siswa mengetahui rumus yang akan digunakan untuk menyelesaikan soal, dan 
siswa mengetahui operasi hitung yang akan digunakan. Pada tahap keterampilan proses (process skill) siswa menentukan prosedur atau langkah-langkah yang akan digunakan untuk menyelesaikan soal, dan siswa dapat melakukan prosedur atau langkah-langkah yang digunakan dengan tepat. Pada tahap penulisan jawaban (encoding) siswa dapat menemukan hasil akhir sesuai langkah-langkah yang digunakan, siswa dapat menunjukkan jawaban akhir dari penyelesaian soal dengan benar, dan siswa dapat menuliskan jawaban akhir sesuai dengan kesimpulan yang dimaksud dalam soal. Penelitian ini penting dilakukan untuk memberikan gambaran kepada guru tentang jenis kesalahan siswa dalam menyelesaikan masalah matematika menggunakan analisis Newman.

\section{METODE PENELITIAN}

Penelitian ini adalah penelitian kualitatif dengan jenis penelitian studi kasus. Subyek penelitian dalam penelitian ini adalah siswa kelas VIIIB SMP Nasional Malang yang berjumlah 27 siswa dengan rincian 18 siswa laki-laki dan 9 siswa perempuan. Prosedur pengumpulan data dalam penelitian ini yaitu tes kemampuan menyelesaikan soal matematika materi teorema Phythagoras, dan wawancara. Soal divalidasi oleh dosen ahli. Tabel 1. Menunjukkan rubrik penskoran analisis kesalahan penyelesaian siswa. Analisis kesalahan penyelesaian siswa mengacu pada Tabel 1.

Tabel 1. Kriteria Pengelompokan Siswa Berdasarkan Nilai Hasil Tes

\begin{tabular}{|c|c|c|}
\hline Tahap Kesalahan & Skor & Kriteria Kesalahan \\
\hline \multirow{4}{*}{$\begin{array}{c}\text { Membaca } \\
\text { (Reading) }\end{array}$} & 0 & Siswa tidak mampu memaknai arti kata yang diminta dalam soal \\
\hline & 1 & $\begin{array}{l}\text { Siswa memaknai arti kata yang diminta tapi tidak sesuai/tidak tepat } \\
\text { dengan permintaan dalam soal }\end{array}$ \\
\hline & 2 & Siswa memaknai arti kata yang diminta tapi kurang tepat \\
\hline & 3 & Siswa memaknai arti kata yang diminta dengan tepat \\
\hline \multirow{4}{*}{$\begin{array}{l}\text { Memahami } \\
\text { (Comprehension) }\end{array}$} & 0 & $\begin{array}{l}\text { Siswa tidak menuliskan informasi yang diketahui dan apa yang } \\
\text { ditanyakan }\end{array}$ \\
\hline & 1 & $\begin{array}{l}\text { Siswa menuliskan informasi yang diketahui dan apa yang ditanyakan } \\
\text { tapi tidak sesuai/tidak tepat dengan permintaan dalam soal }\end{array}$ \\
\hline & 2 & $\begin{array}{l}\text { Siswa menuliskan informasi yang diketahui dan apa yang ditanyakan } \\
\text { tapi kurang tepat }\end{array}$ \\
\hline & 3 & $\begin{array}{l}\text { Siswa menuliskan informasi yang diketahui dan apa yang ditanyakan } \\
\text { dengan tepat }\end{array}$ \\
\hline \multirow{3}{*}{$\begin{array}{l}\text { Transformasi } \\
\text { (Transformation) }\end{array}$} & 0 & $\begin{array}{l}\text { Siswa tidak menuliskan cara atau langkah-langkah dan tidak menuliskan } \\
\text { rumus yang akan digunakan }\end{array}$ \\
\hline & 1 & $\begin{array}{l}\text { Siswa menuliskan cara atau langkah-langkah dan menuliskan rumus } \\
\text { yang akan digunakan tapi kurang sesuai/kurang tepat dengan permintaan } \\
\text { dalam soal }\end{array}$ \\
\hline & 2 & $\begin{array}{l}\text { Siswa menuliskan cara atau langkah-langkah dan menuliskan rumus } \\
\text { yang akan digunakan dengan tepat }\end{array}$ \\
\hline \multirow{4}{*}{$\begin{array}{l}\text { Keterampilan } \\
\text { Proses (Process } \\
\quad \text { Skill) }\end{array}$} & 0 & Siswa tidak dapat melakukan perhitungan \\
\hline & 1 & $\begin{array}{l}\text { Siswa dapat melakukan perhitungan tetapi tidak sesuai dengan yang } \\
\text { dimaksudkan pada soal }\end{array}$ \\
\hline & 2 & $\begin{array}{l}\text { Siswa dapat melakukan perhitungan besarnya nilai tetapi tidak dapat } \\
\text { menentukan hasil akhir }\end{array}$ \\
\hline & 3 & $\begin{array}{l}\text { Siswa dapat melakukan perhitungan besarnya nilai dan dapat } \\
\text { menentukan hasil akhir }\end{array}$ \\
\hline \multirow{3}{*}{$\begin{array}{l}\text { Penulisan Jawaban } \\
\text { (Encoding) }\end{array}$} & 0 & Siswa tidak menuliskan jawaban akhir yang diminta pada soal \\
\hline & 1 & Siswa salah menuliskan jawaban akhir yang diminta pada soal \\
\hline & 2 & Siswa menuliskan jawaban akhir yang diminta pada soal \\
\hline
\end{tabular}




\section{HASIL DAN PEMBAHASAN}

Hasil tes siswa dianalisis menggunanakan pedoman rubrik penskoran analisis kesalahan Newman. Perolehan skor pada masing-masing item tes dijumlahkan untuk setiap siswa. Berdasarkan skor yang diperoleh, siswa dikelompokkan menurut kelompok atas, tengah dan bawah. Berikut Tabel 2. Hasil analisis tes siswa menggunakan analisis Newman.

\section{Tabel 2. Hasil Analisis Tes Siswa Berdasarkan Analisis Newman}

\begin{tabular}{lcl}
\hline Nama & Skor & Keterangan Hasil Tes \\
\hline AIA & 50 & Tengah \\
ATA & 38 & Bawah \\
DMG & 36 & Bawah \\
DA & 45 & Bawah \\
DF & 45 & Bawah \\
EDP & 45 & Bawah \\
ER & 38 & Bawah \\
FR & 57 & Atas \\
GDA & 36 & Bawah \\
HSWA & 53 & Atas \\
HIHA & 38 & Bawah \\
HR & 57 & Atas \\
JFF & 39 & Bawah \\
MAAP & 52 & Tengah \\
MFW & 39 & Bawah \\
MIMP & 50 & Tengah \\
NSW & 50 & Tengah \\
PDA & 50 & Tengah \\
RR & 39 & Bawah \\
RR & 36 & Bawah \\
SJ & 53 & Atas \\
SAP & 36 & Bawah \\
VO & 38 & Bawah \\
WFN & 53 & Atas \\
YAP & 51 & Tengah \\
YIP & 52 & Tengah \\
YNAO & 38 & Bawah \\
\hline & & \\
& &
\end{tabular}

Untuk masing-masing kelompok tes, dua siswa diambil secara acak seperti ditunjukkan pada Tabel 3. Dengan demikian terdapat enam subjek penelitian wawancara. Wawancara dilakukan untuk mengklarifikasi subjek penelitian atas kesalahan dalam menyelesaikan tes.

Tabel 3. Daftar Subjek Penelitian

\begin{tabular}{ccc}
\hline Kode Siswa & Kelompok & Kode Subjek \\
\hline$A_{8}$ & Atas & $S_{1}$ \\
$A_{10}$ & Atas & $S_{2}$ \\
$A_{14}$ & Tengah & $S_{3}$ \\
$A_{17}$ & Tengah & $S_{4}$ \\
$A_{4}$ & Bawah & $S_{5}$ \\
$A_{20}$ & Bawah & $S_{6}$ \\
\hline
\end{tabular}

Analisis kesalahan Newman siswa diuraikan menurut lima tahapan analisis, yaitu kesalahan membaca, kesalahan memahami, kesalahan transformasi, kesalahan keterampilan proses, dan kesalahan penulisan jawaban. Berikut pembahasan kesalahan siswa dalam menyelesaikan soal matematika kelas VIII B SMP Nasional Malang. Analisis kesalahan Newman pertama adalah kesalahan membaca. Subjek penelitian yang melakukan kesalahan jenis ini adalah subjek penelitian yang tidak dapat membaca atau mengenal simbol-simbol 
dalam soal dan tidak mampu memaknai arti kata, istilah atau simbol dalam soal. Subjek penelitian yang melakukan kesalahan membaca pada soal nomor 1 adalah subjek penelitian $S_{5}$, pada soal nomor 2 tidak ada subjek penelitian yang melakukan kesalahan, pada soal nomor 3 tidak ada subjek penelitian yang melakukan kesalahan, pada soal nomor 4 kesalahan membaca ada pada subjek penelitian $S_{1}, S_{2}, S_{3}$, sedangkan pada soal nomor 5 kesalahan membaca ada pada subjek penelitian $S_{6}$. Kesalahan membaca pada siswa seperti siswa tidak dapat membaca atau mengenal simbol-simbol dalam soal dan tidak mampu memaknai arti kata, istilah atau simbol dalam soal dipengaruhi oleh rendahnya kemampuan penyelesaian masalah siswa. Kemampuan matematis dan tingkat kognitif mempengaruhi kemampuan penyelesaian masalah siswa (Tambychik \& Meerah, 2010).

Kesalahan kedua berdasarkan tahapan analisis kesalahan Newman adalah kesalahan memahami. Subjek penelitian yang melakukan kesalahan jenis ini adalah subjek penelitian yang tidak mampu memahami informasi yang diketahui dengan lengkap dan tidak memahami apa saja yang ditanyakan dengan lengkap. Subjek penelitian yang melakukan kesalahan memahami pada soal nomor 1 adalah subjek penelitian $S_{5}$ dan $S_{6}$, pada soal nomor 2 kesalahan memahami terjadi pada subjek penelitian $S_{6}$, pada soal nomor 3 kesalahan memahami terjadi pada subjek penelitian $S_{5}$, pada soal nomor 4 kesalahan memahami terjadi pada subjek penelitian $S_{1}, S_{3}, S_{4}$, $S_{5}$, dan $S_{6}$, sedangkan pada soal nomor 5 kesalahan memahami terjadi pada subjek penelitian $S_{4}$, $S_{5}$, dan $S_{6}$. Kesalahan reading comprehension terjadi pada siswa di awal penyelesaian algoritma atau komputasi (Flagg, 2014).

Kesalahan ketiga berdasarkan tahapan analisis kesalahan Newman adalah kesalahan transformasi. Subjek penelitian yang melakukan kesalahan jenis ini adalah subjek penelitian yang tidak mengetahui apa saja rumus dan tahapan operasi hitung yang akan digunakan untuk menyelesaikan soal. Dari hasil penelitian yang didapatkan dapat diketahui bahwa pada soal nomor 1 kesalahan transformasi terjadi pada subjek penelitian $S_{4}$ dan $S_{5}$, pada soal nomor 2 tidak ada subjek penelitian yang melakukan kesalahan, pada soal nomor 3 tidak ada subjek penelitian yang melakukan kesalahan, pada soal nomor 4 kesalahan transformasi terjadi pada subjek penelitian $S_{1}, S_{2}, S_{3}$, dan $S_{4}$, sedangkan pada soal nomor 5 kesalahan transformasi terjadi pada subjek penelitian $S_{4}$ dan $S_{6}$.

Kesalahan keempat berdasarkan tahapan analisis kesalahan Newman adalah kesalahan keterampilan proses. Subjek penelitian yang melakukan kesalahan jenis ini adalah subjek penelitian yang tidak mengetahui dan tidak mampu melakukan prosedur atau langkah-langkah yang digunakan dengan tepat penyelesaian soal. Dari hasil penelitian yang didapatkan dapat diketahui bahwa pada soal nomor 1 kesalahan keterampilan proses terjadi pada subjek penelitian $S_{4}, S_{5}$, dan $S_{6}$, pada soal nomor 2 kesalahan keterampilan proses terjadi pada subjek penelitian $S_{6}$, pada soal nomor 3 tidak ada subjek penelitian yang melakukan kesalahan, pada soal nomor 4 kesalahan keterampilan proses terjadi pada subjek penelitian $S_{1}, S_{2}, S_{3}$, dan $S_{4}$, sedangkan pada soal nomor 5 kesalahan keterampilan proses terjadi pada subjek penelitian $S_{2}, S_{4}$, dan $S_{6}$.

Kesalahan kelima berdasarkan tahapan analisis kesalahan Newman adalah kesalahan penulisan akhir. Subjek penelitian yang melakukan kesalahan jenis ini adalah subjek penelitian yang tidak mampu menuliskan jawaban akhir sesuai dengan kesimpulan yang dimaksud dalam soal. Dari hasil penelitian yang didapatkan dapat diketahui bahwa pada soal nomor 1 kesalahan penulisan jawaban akhir terjadi pada subjek penelitian $S_{3}, S_{4}, S_{5}$, dan $S_{6}$, pada soal nomor 2 kesalahan penulisan jawaban akhir terjadi pada subjek penelitian $S_{6}$, pada soal nomor 3 kesalahan penulisan jawaban akhir terjadi pada subjek penelitian $S_{6}$, pada soal nomor 4 kesalahan penulisan jawaban akhir terjadi pada subjek penelitian $S_{1}, S_{2}, S_{3}$ dan $S_{4}$, sedangkan pada soal nomor 5 kesalahan penulisan jawaban akhir terjadi pada subjek penelitian $S_{2}, S_{4}$, dan $S_{6}$. 


\section{PENUTUP}

Berdasarkan penelitian analisis kesalahan siswa dalam menyelesaikan soal matematika menggunakan analisis Newman, beberapa kesimpulan dari penelitian ini antara lain: (1) Kesalahan dalam membaca soal matematika sebanyak 5 subjek; (2) Kesalahan dalam memahami soal matematika sebanyak 12 subjek; (3) Kesalahan dalam transformasi sebanyak 8 subjek; (4) Kesalahan keterampilan proses sebanyak 11 subjek; dan (5) Kesalahan penulisan jawaban akhir sebanyak 13 subjek. Pada kesalahan membaca, siswa tidak mampu memaknai arti setiap kata, istilah atau simbol dalam soal. Pada kesalahan memahami, siswa tidak mampu memahami apa saja yang diketahui dengan lengkap dan tidak mampu memahami apa saja yang ditanyakan. Pada kesalahan transformasi, siswa tidak mengetahui apa saja rumus yang akan digunakan dan tidak mengetahui operasi hitung yang akan digunakan. Pada kesalahan keterampilan proses, siswa tidak mengetahui prosedur atau langkah-langkah yang akan digunakan. Pada kesalahan penulisan akhir, siswa tidak menemukan hasil akhir yang sesuai dengan langkah-langkah yang digunakan dan tidak menuliskan jawaban akhir sesuai dengan kesimpulan yang dimaksud dalam soal.

Saran peneliti kaitannya dengan hasil penelitian ini antara lain guru hendaknya meminta siswa memahami maksud soal, memberikan latihan yang menekankan pada keterampilan berhitung dan keterampilan menyelesaikan masalah dengan prosedur yang tepat. Selain itu, penelitian ini hanya berfokus pada analisis lima tahapan kesalahan Newman, oleh karena itu peneliti selanjutnya dapat mengembangkan tahapan analisis kesalahan secara lebih spesifik sehingga dapat memperkaya khasanah lingkup penelitian berkaitan dengan analisis kesalahan penyelesaian masalah matematika siswa.

\section{DAFTAR PUSTAKA}

Flagg, V. L. 2014. Newman's Error Analysis And Mathematical Language: Diagnosing Mathematical Errors On Word Problems Made By 4th Graders Who Attend A Low SES School (Unpublished doctoral thesis). Mecer University, USA.

Hariyani, S., Yuwono, I., Sa'dijah, C., \& Rahardjo, S. 2016. Math Problem Solving Phases on Thinking Outside The Box. IOSR Journal of Research \& Method in Education (IOSRJRME), 6(4), 43-48.

Intaros, P., Inprasitha, M., \& Srisawadi, N. 2014. Students' Problem Solving Strategies in Problem Solving-mathematics Classroom. 5th World Conference on Educational Sciences, 116, 4119-4123.

Karnasih, I. 2015. Analisis Kesalahan Newman Pada Soal Cerita Matematis (Newman's Error Analysis In Mathematical Word Problems). PARADIKMA JURNAL PENDIDIKAN MATEMATIKA, 8(1).

Tambychik, T., \& Meerah, T. S. M. 2010. Students' Difficulties in Mathematics ProblemSolving: What do they Say? International Conference on Mathematics Education Research 2010 (ICMER 2010), 8, 142-151. 